\title{
Effects of feed and health interventions on small ruminant production in mixed crop-livestock systems in Southern Mali
}

\author{
Augustine A. Ayantunde ${ }^{1 *}$ Clarisse Umutoni ${ }^{1,2}$ Théophile \\ Dembele $^{3}$ Koita Seydou ${ }^{3}$ Oumar Samake ${ }^{3}$
}

\begin{abstract}
Keywords
small ruminant, livestock numbers, mixed farming, household food security, Sahel
\end{abstract}

\author{
Submitted: 23 November 2018 \\ Accepted: 24 April 2019 \\ Published: 12 July 2019
}

DOI: $10.19182 /$ remvt.31747

\begin{abstract}
Summary
In Mali, small ruminants are a necessary part of mixed crop and livestock systems, and they fulfill various roles in the food security of households as sources of meat and milk, and means of additional income to meet food and cash needs. However, small ruminant production is challenged by the poor performance of animals, which is mainly caused by inadequate nutrition and diseases. A pilot study that combined feed and health interventions was conducted in two villages, Sirakele and Zanzoni in Koutiala District in the south of the country. The objective was to assess the effects of the combined interventions on small ruminant production in mixed crop-livestock systems. Zanzoni served as control, and Sirakele received both feed and health interventions. Twenty households were randomly selected in each village and the study lasted one year, from August 2016 to August 2017. Results showed that within a year the average goat and sheep flock size in the feed and health intervention group doubled, whereas it mostly remained the same in the control group. The mortality rate was significantly lower in the treatment group than in the control one. In addition, the goats and sheep gained $42.98 \pm 3.28$ and $47.12 \pm 2.73 \mathrm{~g} /$ day in the treatment group, whereas they only gained $22.59 \pm 2.29$ and $16.58 \pm 2.74 \mathrm{~g} /$ day in the control group, respectively. The results confirmed that feed and health interventions significantly improved small ruminant production.
\end{abstract}

- To cite this article: Ayantunde A.A., Umutoni C., Dembele T., Seydou K., Samake O., 2019. Effects of feed and health interventions on small ruminant production in mixed crop-livestock systems in Southern Mali. Rev. Elev. Med. Vet. Pays Trop., 72 (2): 65-72, doi: 10.19182/remvt.31747

\section{INTRODUCTION}

Small ruminants are a necessary part of mixed crop and livestock systems in Mali and they fulfill various roles in household food security as a source of meat and milk, and means of additional income to meet food and cash needs (Wilson, 1986; Ba et al., 1996). In West African Sahel, the majority of farmers raise small ruminants for immediate source of income, insurance against emergencies, and to mitigate effects in case of crop failures (Wilson, 1991). Small ruminants also produce manure, which is an invaluable source of organic

1. International Livestock Research Institute (ILRI), BP 1496, Ouagadougou, Burkina Faso.

2. Current address: International Crops Research Institute for the Semi-Arid Tropics (ICRISAT), Niamey, Niger.

3. Association malienne d'éveil au développement durable (AMEDD), Koutiala, Mali.

*Corresponding author

Email: a.ayantunde@cgiar.org

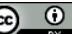

https://creativecommons.org/licenses/by/4.0/ matter to improve soil fertility. In Mali, about $90 \%$ of the households own sheep and goats, as they are important for livelihood strategies of poor rural areas (Ba et al., 1996). Rural women and youth are much involved in small ruminant rearing which provides them with employment opportunities (Wilson, 1991; Lebbie, 2004). The short generation intervals of small ruminants compared to those of cattle allow for rapid flock growth provided there are adequate nutrition and veterinary care. Moreover, small ruminants tend to withstand drought much better (Lebbie, 2004). Wilson (1991) reported that, during the early 1980s' drought in the Sahel, cattle losses were over $80 \%$, whereas those of small ruminants were not more than $50 \%$.

The potential for rapid flock growth and the varied functions of small ruminants in mixed crop-livestock systems could be means to improve household food security and poverty alleviation of smallholder farmers. However, small ruminant production in Mali is challenged by a poor performance mainly caused by inadequate nutrition and diseases (Wilson, 1986; Ba et al., 1996). Given the low inputs into sheep and goat production from smallholder farmers, supplementary feeding is often on an ad hoc basis (Ayantunde et al., 2014) and the animals are rarely vaccinated or regularly treated for diseases (Ba et al., 1996). 
Consequently, a high mortality rate is common in small ruminant flocks in Mali (Ba et al., 1996) as it is the case in other Sahelian countries. Mortality could be reduced by vaccinating small ruminants against main diseases such as pasteurellosis and peste des petits ruminants (PPR), and by deworming them. In addition to healthcare, strategic supplementation is essential to improve their performance (Ben Salem and Smith, 2008; Nantoumé et al., 2011; Konlan et al., 2017). Previous studies have yielded promising results on feed and health interventions to improve small ruminant production in Ghana under the Africa RISING project (Avornyo et al., 2015; Konlan et al., 2017).

The underlying hypothesis for this pilot study was that combining improved management practices would result in higher animal productivity, income, and household food security than one technology alone. The objective was to assess the effects of combined feed and health interventions on small ruminant production in mixed crop-livestock systems in Southern Mali. Specific objectives were: (i) to assess the effects of feed and health interventions on sheep and goat live-weight changes, flock dynamics (birth, death, and offtake) and manure production, and (ii) to quantify the costs and benefits of feed and health package in smallholder small ruminant production.

\section{MATERIALS AND METHODS}

\section{Study sites}

The study was performed in Sirakele $\left(12.51^{\circ} \mathrm{N}, 5.48^{\circ} \mathrm{W}\right)$ and Zanzoni $\left(12.61^{\circ} \mathrm{N}, 5.57^{\circ} \mathrm{W}\right)$ villages in Koutiala District in Southern Mali. Sirakele is a village in the rural commune of Songoua at about 15 kilometers north of Koutiala, and Zanzoni is in the commune of Fakolo at about 35 kilometers north of Koutiala. Koutiala District is the main cotton production area of Mali. The project villages are in the 'zones of influence' of the Africa Research in Sustainable Intensification for the Next Generation (Africa RISING) program in Mali, supported by the United States Agency for International Development (USAID). Africa RISING aims at creating opportunities for smallholder farms to move out of hunger and poverty through sustainably intensified farming systems that improve food, nutrition, and income security, particularly for women and children, and conserve or enhance the natural resource base.

Both villages are in a region where mixed crop-livestock systems prevail. Both sites have a Sudanian climate characterized by a dry and a rainy season that last about six months each. The dry season is usually between November and April, and the rainy season between May and October. Annual rainfall varies between 750 and $1100 \mathrm{~mm}$. Crop farming and livestock husbandry are the main sources of household food and income. The main feed resources are natural pastures, crop residues and agro-industrial by-products. The feed resources in both sites were similar to those reported by Umutoni and Ayantunde (2014) in Koutiala and Bougoni districts in Southern Mali.

\section{Household selection}

Sheep and goat flocks belonging to twenty households in each village were monitored during a year (August 2016 - August 2017). The forty households were randomly selected based on the ownership of sheep and or goats, and the willingness to participate in the study, which entailed monitoring animals for about a year. The two villages were randomly allocated to one of the two groups: Zanzoni households were in the control group, whereas Sirakele households were in the treatment group.

\section{Animal management}

The sheep and goat flocks in the treatment group received vaccination against pasteurellosis, peste des petits ruminants (PPR) and trypanosomosis, deworming and regular health care in case of any sickness, and supplementary feed (300 g of cottonseed cake per animal per day) throughout the 12 months. Cottonseed cake was used as supplement as it was readily available in the sites because of the widespread cultivation of cotton. The amount of cottonseed cake (200-300 g per animal) was based on Konlan et al. (2017) in a similar study in Ghana. The physiological status to determine the amounts of supplement to be distributed was not included as it was difficult to adjust quantities in rural conditions. Ovipeste and Pastovin vaccines (produced by the Laboratoire central vétérinaire in Bamako) were used against PPR and pasteurellosis, respectively. Sheep and goats under feed and health interventions were vaccinated once a year against PPR at the dosage of $1 \mathrm{ml}$ per animal, and twice a year against pasteurellosis at the dosage of $2 \mathrm{ml}$ per animal. The treatment animals were also vaccinated against trypanosomosis with Veriben B12 (diminazene, antipyrine and long-lasting-effect vitamin B12) (CEVA), and Kelamidium (CAPHAVET). Prophylaxis in the form of antibiotic and multivitamin injections, and deworming were given to the treatment group; tetracycline (oxytetracycline) was injected quarterly; deworming was done twice a year, at the beginning of the study in August and at the end of the rainy season in October using Synanthic (oxfendazole) (Boehringer Ingelheim). The treatment group was also treated for other diseases when necessary.

The flocks in the control group did not receive supplement feed nor health intervention. However, farmers in this group did treat their sick animals though irregularly and offered crop residues particularly sorghum straw, cotton straw and groundnut haulms after the crop harvest, and browses (leaves of shrubs and trees) in the late dry season on an ad hoc basis. In both sites, daily management consisted in letting most sheep and goats graze on natural pastures in the rainy season, and on crop residues in the dry season. Fattening animals, lactating does and ewes, and sick animals were usually kept around the homesteads and fed. Lambs and kids were not allowed to graze until the age of three to four months. Upon return from grazing, the animals in the treatment group were offered cottonseed cakes as supplement, which was often consumed immediately. At night, the animals in both groups were tethered to stakes or penned in enclosures or shelters around the homesteads.

About 94\% of the sheep were of the Djallonke breed, the others were Sahelian long-legged. The latter were mainly males for fattening. The main goat breed was also West African Dwarf (about 96\%) and the others were Sahelian long-legged.

\section{Flock monitoring and data collection}

All the sheep and goats in both groups were ear-tagged and weighed at the beginning of the study. At this time, the total flock in Zanzoni comprised 78 sheep and 84 goats, 162 animals in total, whereas in Sirakele the total flock comprised 106 sheep and 135 goats, 241 animals in total. All the animals in both groups were weighed three days consecutively every month. Average live weight change was estimated by regression of individual live weight on time. All the animals that were weighed at least six times during the year were included in the calculation of average daily gain (ADG). Fewer observations (number of animals) were included in the calculation of the average weights at one and three months of age because of the absence of young animals ( $\leq 3$ month kids and lambs) at monthly weighings as many households did not bring them. However, they were brought for weighing as they became older.

Two field technicians were responsible for monitoring the animals and they visited each household every month to collect data on any change in the flock (demographic event) including birth, death, sale, slaughter, giving out or receiving an animal as a gift, caretaking arrangement, and loss through theft. The data on the occurrence of death in the flocks was used to calculate the mortality rate, i.e. the number of deaths recorded as a percentage of the total flock at the beginning of the study. The offtake rate was calculated as the number of animals sold, slaughtered and given out as a percentage of the total 
flock at the beginning of the study. The manure deposited in enclosures or shelters was collected each morning after the sheep and goats were taken out of the pens in each household in both groups; it was air dried and stored in a bag for weighing every month by the field technicians of the Association malienne d'éveil au développement durable (AMEDD).

\section{Collection of feed and fecal samples}

Two samples of feed resources fed to the experimental animals were collected in the early and late dry seasons. The feed resources were mainly crop residues, browses and agro-industrial by-products. In total, 46 feed samples were collected and ground to pass through a 2-mm sieve for laboratory analysis of their chemical composition. Two fecal (manure) samples of $0.5 \mathrm{~kg}$ fresh weight were collected monthly from each household and air dried. Collected samples for each household were combined per season (wet/rainy, early dry and late dry) and ground. In total 120 fecal samples were prepared for laboratory analysis.

\section{Laboratory analysis of feed and fecal samples}

Samples of feed resources in the sites were collected mainly in the early and late dry seasons (from October 2016 to May 2017), air dried and prepared for laboratory analyses. Feed samples were analyzed for dry matter (DM), ash content, nitrogen $(\mathrm{N})$, fiber components (neutral detergent fiber [NDF], acid detergent fiber [ADF], acid detergent lignin [ADL]) and in vitro organic matter digestibility (IVOMD) with the near-infrared reflectance spectroscopy (NIRS) technique. Sample fineness for NIRS analysis was $2 \mathrm{~mm}$. The wavelength range to estimate the chemical composition was 1100 to 2500 nanometer. NIRS is an indirect analytical method based on the development of empirical models in which the concentration of a feed constituent is predicted from complex spectral data (De Boever et al., 1995). Crude protein was estimated from nitrogen content (nitrogen $\times 6.25$ ). Metabolizable energy (Mcal $/ \mathrm{kg}$ DM) was derived from IVOMD. The fecal samples were analyzed for DM, organic matter $(\mathrm{OM}), \mathrm{N}$, and phosphorus $(\mathrm{P})$ concentrations.

\section{Statistical analysis}

Data analysis was performed with SAS (1987) using means procedures for descriptive statistics. The T-test was used to compare the means of demographic events (e.g. birth rate, mortality rate, offtake rate), average daily gains, quantities of manure collected per household and costs and benefits between the control and treatment groups. Unless otherwise specified, the level of significance was set at $\mathrm{p}<0.05$.

\section{RESULTS}

\section{Flock structure and dynamics}

The average flock size per household at the beginning of the study for sheep was $3.90 \pm 0.82$ in the control and $5.30 \pm 0.81$ in the feed and health intervention groups (Table I). The average goat flock size was $4.20 \pm 0.97$ in the control group and $6.75 \pm 1.24$ in the treatment one. After a year, the sheep and goat flock sizes of the control group remained mostly the same as those at the beginning of the study, whereas they doubled with feed and health interventions within the same period (Table I). In the treatment group the number of sheep increased from 106 at the beginning of the study to 238 at the end, and the number of goats increased from 135 to 254 (Figure 1). Results on flock dynamics showed significant differences in the birth, mortality and offtake rates between control and treatment groups, e.g.
$30.4 \%$ mortality rate in the control group versus $13.3 \%$ in the treatment group (Table II).

\section{Body weight development and growth}

The results showed that feed and health interventions had significant effects on body weight development and ADG of sheep and goats (Table III). The ADG of sheep and goats in the control group were $16.58 \pm 2.74$ and $22.59 \pm 2.29 \mathrm{~g} /$ day, respectively, whereas those of sheep and goats in the treatment group were almost double, 47.12 \pm 2.73 and $42.98 \pm 3.28 \mathrm{~g} /$ day, respectively. At one year of age, sheep and goats in the treatment group weighed significantly more than those in the control group (Table III).

\section{Manure production and nutrient content}

Results of manure collected from sheep and goats by households under control and feed-health interventions are presented in Table IV.

\section{Table I}

Flock composition at the beginning and at the end of the study in two villages (one control, the other with feed and health interventions) in Southern Mali

\begin{tabular}{|c|c|}
\hline $\begin{array}{c}\text { Zanzoni } \\
\text { Control }\left(n=20^{*}\right) \\
(\text { mean } \pm \text { SE })\end{array}$ & $\begin{array}{c}\text { Sirakele } \\
\text { Treatment } \\
\left(n=20^{*}\right) \\
(\text { mean } \pm \text { SE })\end{array}$ \\
\hline
\end{tabular}

Beginning of the study (August 2016)

\begin{tabular}{llr} 
Average num. of male sheep & $0.75 \pm 0.33^{\mathrm{a}}$ & $1.10 \pm 0.25^{\mathrm{a}}$ \\
Average num. of female sheep & $3.15 \pm 0.69^{\mathrm{a}}$ & $4.20 \pm 0.70^{\mathrm{a}}$ \\
Average total num. of sheep & $3.90 \pm 0.82^{\mathrm{a}}$ & $5.30 \pm 0.81^{\mathrm{a}}$ \\
Average num. of male goats & $0.50 \pm 0.20^{\mathrm{a}}$ & $1.60 \pm 0.42^{\mathrm{b}}$ \\
Average num. of female goats & $3.70 \pm 0.81^{\mathrm{a}}$ & $5.15 \pm 0.97^{\mathrm{a}}$ \\
Average total num. of goats & $4.20 \pm 0.97^{\mathrm{a}}$ & $6.75 \pm 1.24^{\mathrm{a}}$ \\
& & \\
\hline End of the study (August 2017) & & \\
Average num. of male sheep & $0.65 \pm 0.22^{\mathrm{a}}$ & $5.20 \pm 0.93^{\mathrm{b}}$ \\
Average num. of female sheep & $2.95 \pm 0.73^{\mathrm{a}}$ & $6.70 \pm 0.93^{\mathrm{b}}$ \\
Average total num. of sheep & $3.60 \pm 0.84^{\mathrm{a}}$ & $11.90 \pm 1.56^{\mathrm{b}}$ \\
Average num. of male goats & $1.15 \pm 0.33^{\mathrm{a}}$ & $3.90 \pm 0.89^{\mathrm{b}}$ \\
Average num. of female goats & $3.45 \pm 0.72^{\mathrm{a}}$ & $8.80 \pm 1.35^{\mathrm{b}}$ \\
Average total num. of goats & $4.60 \pm 0.99^{\mathrm{a}}$ & $12.70 \pm 2.04^{\mathrm{b}}$
\end{tabular}

* Num. of households; SE: standard error; ${ }^{\mathrm{a}, \mathrm{b}}$ Values followed by different superscripts on the same line are statistically significant $(\mathrm{p}<0.05)$

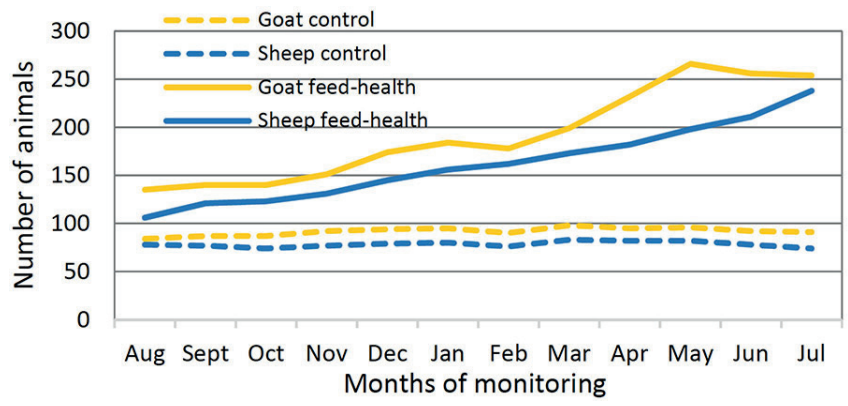

Figure 1: Sheep and goat flock growth in Koutiala District, Southern Mali (August 2016 - August 2017). 


\section{Table II}

Flock dynamics of sheep and goats in two villages (one control, the other with feed and health interventions) in Southern Mali between August 2016 and August 2017

\begin{tabular}{|c|c|c|}
\hline & $\begin{array}{c}\text { Zanzoni } \\
\text { Control } \\
\left(\mathrm{n}=20^{*}\right) \\
(\text { mean } \pm \mathrm{SE})\end{array}$ & $\begin{array}{c}\text { Sirakele } \\
\text { Treatment } \\
\left(n=20^{*}\right) \\
(\text { mean } \pm \text { SE) }\end{array}$ \\
\hline $\begin{array}{l}\text { Average num. of births / } \\
\text { household }\end{array}$ & $5.72 \pm 2.10^{\mathrm{a}}$ & $15.20 \pm 3.41^{b}$ \\
\hline Birth rate $(\%)$ & $69.9 \pm 3.4^{\mathrm{a}}$ & $126.7 \pm 4.9^{b}$ \\
\hline Mortality rate (\%) & $30.4 \pm 2.7^{a}$ & $13.3 \pm 3.1^{b}$ \\
\hline Offtake rate (\%) & $30.4 \pm 2.9^{a}$ & $38.8 \pm 3.1^{b}$ \\
\hline $\begin{array}{l}\text { Average price / animal sold } \\
\text { (FCFA) }\end{array}$ & $19,777 \pm 841^{a}$ & $24,887 \pm 964^{b}$ \\
\hline $\begin{array}{l}\text { Average income from animal } \\
\text { sale / household (FCFA) }\end{array}$ & $38,537 \pm 7,560^{a}$ & $169,125 \pm 26,545^{b}$ \\
\hline $\begin{array}{l}\text { Average num. of animals } \\
\text { purchased / household }\end{array}$ & $0.02 \pm 0.01^{\mathrm{a}}$ & $0.34 \pm 0.04^{\mathrm{a}}$ \\
\hline $\begin{array}{l}\text { Average num. of animals } \\
\text { slaughtered for consumption } \\
\text { / household }\end{array}$ & $0.04 \pm 0.02^{\mathrm{a}}$ & $0.09 \pm 0.02^{\mathrm{a}}$ \\
\hline $\begin{array}{l}\text { Average num. of animals } \\
\text { given out as gift / caretaking } \\
\text { / household }\end{array}$ & $0.04 \pm 0.01^{\mathrm{a}}$ & $0.03 \pm 0.01^{\mathrm{a}}$ \\
\hline $\begin{array}{l}\text { Average num. of animals } \\
\text { received for caretaking / } \\
\text { household }\end{array}$ & $0.01 \pm 0.01^{\mathrm{a}}$ & $0.08 \pm 0.03^{\mathrm{a}}$ \\
\hline $\begin{array}{l}\text { Average num. of animals lost } \\
\text { to theft / household }\end{array}$ & $0.03 \pm 0.01^{\mathrm{a}}$ & $0.04 \pm 0.02^{\mathrm{a}}$ \\
\hline
\end{tabular}

* Num. of households; Initially there were 241 sheep and goats in Sirakele, and 162 sheep and goats in Zanzoni; SE: standard error; ${ }^{\mathrm{a}, \mathrm{b}}$ Values followed by different superscripts on the same line are statistically significant $(\mathrm{p}<0.05)$.

\section{Table III}

Weight and growth of sheep and goats in two villages (one control, the other with feed and health interventions) in Southern Mali between August 2016 and August 2017

\begin{tabular}{|c|c|c|c|c|}
\hline & \multicolumn{2}{|c|}{ Zanzoni Control } & \multicolumn{2}{|c|}{ Sirakele Treatment } \\
\hline & $\mathbf{n}$ & $($ mean $\pm \mathrm{SE})$ & $\mathbf{n}$ & $($ mean $\pm \mathrm{SE})$ \\
\hline \multicolumn{5}{|l|}{ Goats } \\
\hline $\begin{array}{l}\text { Weight at } 1 \text { month } \\
(\mathrm{kg})\end{array}$ & 10 & $2.45 \pm 0.16^{a}$ & 36 & $2.62 \pm 0.09^{a}$ \\
\hline $\begin{array}{l}\text { Weight at } 3 \text { months } \\
(\mathrm{kg})\end{array}$ & 36 & $5.65 \pm 0.17^{a}$ & 101 & $5.71 \pm 0.13^{\mathrm{a}}$ \\
\hline Weight at 1 year (kg) & 14 & $12.89 \pm 0.80^{\mathrm{a}}$ & 36 & $16.78 \pm 0.34^{b}$ \\
\hline ADG (g/day) & 131 & $22.59 \pm 2.29^{a}$ & 311 & $42.98 \pm 3.28^{b}$ \\
\hline \multicolumn{5}{|l|}{ Sheep } \\
\hline $\begin{array}{l}\text { Weight at } 1 \text { month } \\
(\mathrm{kg})\end{array}$ & 6 & $2.92 \pm 0.27^{a}$ & 10 & $3.00 \pm 0.13^{\mathrm{a}}$ \\
\hline $\begin{array}{l}\text { Weight at } 3 \text { months } \\
(\mathrm{kg})\end{array}$ & 15 & $7.23 \pm 0.39^{a}$ & 34 & $6.75 \pm 0.22^{\mathrm{a}}$ \\
\hline Weight at 1 year (kg) & 3 & $18.5 \pm 0.76^{a}$ & 17 & $22.34 \pm 0.88^{b}$ \\
\hline ADG (g/day) & 117 & $16.58 \pm 2.74^{\mathrm{a}}$ & 225 & $47.12 \pm 2.73^{b}$ \\
\hline
\end{tabular}

SE: standard error; ADG: average daily gain; ${ }^{a, b}$ Values followed by different superscripts on the same line are statistically significant $(\mathrm{p}<0.05)$.

\section{Table IV}

Manure collected from sheep and goats by household in two villages (one control, the other with feed and health interventions) between September 2016 and August 2017 in Southern Mali

$\begin{array}{cc}\text { Zanzoni } & \text { Sirakele } \\ \text { Control } & \text { Treatment } \\ \left(\mathrm{n}=20^{*}\right) & \left(\mathrm{n}=\mathbf{2 0}^{*}\right) \\ (\text { mean } \pm \mathrm{SE}) & (\text { mean } \pm \mathrm{SE})\end{array}$

\section{Early dry season (October-January)}

Collected manure (g DM/day)

Collected manure

(g DM/animal/day)

Collected manure $\quad 5.14 \pm 0.19^{\mathrm{a}} \quad 5.88 \pm 0.24^{\mathrm{a}}$

(g DM/day/animal/kg live weight)

Nitrogen concentration $\left(g / k g\right.$ DM) $20.95 \pm 0.31^{\mathrm{a}} \quad 21.35 \pm 0.29^{\mathrm{a}}$

Phosphorus concentration $\quad 3.76 \pm 0.13^{\mathrm{a}} \quad 4.96 \pm 0.14^{\mathrm{b}}$

(g/kg DM)

Manure nitrogen output (g/day) $\quad 16.48 \pm 0.81^{\mathrm{a}} \quad 37.03 \pm 1.47^{\mathrm{b}}$

Manure phosphorus output $\quad 2.81 \pm 0.14^{\mathrm{a}} \quad 8.64 \pm 0.43^{\mathrm{b}}$

(g/day)

Manure nitrogen output $\quad 1.98 \pm 0.07^{\mathrm{a}} \quad 2.57 \pm 0.10^{\mathrm{a}}$

(g/animal/day)

Manure phosphorus output $\quad 0.35 \pm 0.02^{\mathrm{a}} \quad 0.60 \pm 0.03^{\mathrm{a}}$

(g/animal/day)

\section{Late dry season (February-May)}

Collected manure (g DM/day)

Collected manure

(g DM/animal/day)

Collected manure

(g DM/day/animal/kg live weight)

Nitrogen concentration

(g/kg DM)

Phosphorus concentration

(g/kg DM)

Manure nitrogen output (g/day)

$891 \pm 49^{\mathrm{a}}$

$2392 \pm 104^{b}$

$102 \pm 4.06^{\mathrm{a}}$

$121.52 \pm 4.52^{b}$

Manure phosphorus output

(g/day)

Manure nitrogen output

(g/animal/day)

Manure phosphorus output

(g/animal/day)

$5.67 \pm 0.20^{\mathrm{a}}$

$5.68 \pm 0.21^{\mathrm{a}}$

$21.15 \pm 0.39^{a}$

$20.89 \pm 0.34^{\mathrm{a}}$

$3.89 \pm 0.15^{\mathrm{a}}$

$3.74 \pm 0.19^{a}$

$18.74 \pm 1.04^{\mathrm{a}}$

$50.51 \pm 2.60^{b}$

$3.29 \pm 0.20^{\mathrm{a}}$

$9.04 \pm 0.64^{b}$

$2.14 \pm 0.09^{a}$

$2.52 \pm 0.10^{a}$

$0.38 \pm 0.02^{\mathrm{a}}$

$0.45 \pm 0.03^{a}$

\section{Wet season (June-September)}

Collected manure (g DM/day)

Collected manure

(g DM/animal/day)

Collected manure

(g DM/day/animal/kg live weight)

Nitrogen concentration (g/kg DM)

Phosphorus concentration

(g/kg DM)

Manure nitrogen output (g/day)

$774 \pm 41^{a}$

$2234 \pm 104^{b}$

$95.54 \pm 4.27^{\mathrm{a}} \quad 112.27 \pm 4.64^{\mathrm{b}}$

$5.29 \pm 0.24^{\mathrm{a}}$

$5.62 \pm 0.24^{a}$

Manure phosphorus output

(g/day)

Manure nitrogen output

(g/animal/day)

Manure phosphorus output

(g/animal/day)

$18.83 \pm 0.36^{a}$

$22.73 \pm 0.49^{b}$

$7.21 \pm 0.15^{\mathrm{a}}$

$6.73 \pm 0.11^{\mathrm{a}}$

$14.53 \pm 0.81^{\mathrm{a}} \quad 51.30 \pm 2.78^{\mathrm{b}}$

$5.54 \pm 0.32^{\mathrm{a}} \quad 15.31 \pm 0.82^{\mathrm{b}}$

$1.78 \pm 0.09^{\mathrm{a}} \quad 2.52 \pm 0.11^{\mathrm{a}}$

$0.69 \pm 0.04^{\mathrm{a}}$

$0.75 \pm 0.03^{\mathrm{a}}$

* Num. of households; SE: standard error; DM: dry matter; ${ }^{\text {a,b }}$ Values followed by different superscripts on the same line are statistically significant $(\mathrm{p}<0.05)$. 
The households that received feed-health interventions collected more manure than those under control across all seasons (early dry, late dry and wet seasons). The manure collected was higher in both groups in the late dry season $(102 \pm 4.06 \mathrm{~g} \mathrm{DM} /$ animal/day in the control group, and $121.52 \pm 4.52 \mathrm{~g} \mathrm{DM} / \mathrm{animal} /$ day in the treatment group) than in the wet season.

\section{Nutritional quality of available feed resources}

Apart from natural pastures, the other major feed resources in the sites were crop residues, agro-industrial by-products and browses. Common crop residues included sorghum and cotton straws, cowpea hay and groundnut haulms (Table V). Agro-industrial by-products consisted of cottonseed cakes and maize bran. Cottonseed cakes had the highest crude protein contents. Legume residues (cowpea hay and groundnut haulms) were also high in crude protein and in vitro organic matter digestibility. Browses are important feed resources in the late dry season when there is feed scarcity (Umutoni and Ayantunde, 2014); they generally had high crude protein content but also high lignin content which limited intake and digestibility (Table V).

\section{Partial cost and benefit analysis}

The results of partial cost and benefit analysis of the control and feedhealth interventions showed that the net return in the intervention group was slightly higher than that in control (Table VI) although statistically insignificant. The annual net return in the treatment group was 95,349 $\pm 25,388$ FCFA per household compared to 88,575 $\pm 8,693$ FCFA per household in the control. The sources of revenue were weight gained, manure collected and offtake (Table VI). Costs were for veterinary care and feed.

\section{Table VI}

Partial cost and benefit analysis (FCFA/household/year) from sheep and goat rearing in two villages (one control, the other with feed and health interventions) in Southern Mali

\begin{tabular}{|c|c|c|}
\hline & $\begin{array}{c}\text { Zanzoni } \\
\text { Control }\left(n=20^{*}\right) \\
(\text { mean } \pm S E)\end{array}$ & $\begin{array}{c}\text { Sirakele } \\
\text { Treatment } \\
\left(n=20^{*}\right) \\
(\text { mean } \pm \text { SE) }\end{array}$ \\
\hline $\begin{array}{l}\text { Revenue from } \\
\text { weight gain }{ }^{1}\end{array}$ & $46,596 \pm 3,364^{a}$ & $241,058 \pm 14,189^{b}$ \\
\hline $\begin{array}{l}\text { Revenue from } \\
\text { manure collected }^{2}\end{array}$ & $5,886 \pm 519^{a}$ & $15,474 \pm 844^{b}$ \\
\hline $\begin{array}{l}\text { Revenue from } \\
\text { animal sale }\end{array}$ & $38,537 \pm 7,560^{\mathrm{a}}$ & $169,125 \pm 26,549^{b}$ \\
\hline Gross return & $91,020 \pm 8,738^{\mathrm{a}}$ & $425,657 \pm 34,961^{b}$ \\
\hline $\begin{array}{l}\text { Supplement } \\
\text { (cottonseed cake) } \\
\text { cost }^{3}\end{array}$ & $0^{\mathrm{a}}$ & $300,988 \pm 17,717^{b}$ \\
\hline Veterinary cost ${ }^{4}$ & $2,445 \pm 176^{a}$ & $29,320 \pm 1,725^{b}$ \\
\hline Total cost & $2,445 \pm 176^{a}$ & $330,308 \pm 19,442^{b}$ \\
\hline Net return & $88,575 \pm 8,693^{a}$ & $95,349 \pm 25,388^{a}$ \\
\hline
\end{tabular}

* Num. of households; ${ }^{1} 750 \mathrm{FCFA} / \mathrm{kg}$ live weight based on average sale price of sheep and goats in livestock markets in Koutiala; ${ }^{2} 20$ FCFA/kg air-dried manure; ${ }^{3} 150 \mathrm{FCFA} / \mathrm{kg} ;{ }^{4}$ Pasteurellosis and trypanosomosis vaccinations: $175 \mathrm{FCFA} / \mathrm{ani}$ mal; Treatments and deworming: 200 FCFA/animal/quarter; ${ }^{a, b}$ Values followed by different superscripts on the same line are statistically significant $(\mathrm{p}<0.05)$.

\section{Table V}

Chemical composition of the main feed resources for ruminants in the villages of Zanzoni and Sirakele in Southern Mali (\% on a DM basis)

\begin{tabular}{|c|c|c|c|c|c|c|c|}
\hline Feed & $\mathrm{OM}$ & $\mathrm{CP}$ & NDF & ADF & $\mathrm{ADL}$ & IVOMD & ME \\
\hline \multicolumn{8}{|l|}{ Crop residue } \\
\hline Cowpea (leaf and stem) & 88.46 & 19.06 & 36.06 & 24.57 & 5.65 & 72.03 & 9.83 \\
\hline Groundnut (leaf and stem) & 88.67 & 16.30 & 54.69 & 44.22 & 9.32 & 61.63 & 8.85 \\
\hline Cotton (leaf and stem) & 95.74 & 13.01 & 47.42 & 20.79 & 6.09 & 71.21 & 9.47 \\
\hline Sorghum (leaf and stem) & 94.41 & 4.23 & 71.59 & 46.29 & 6.38 & 51.91 & 7.68 \\
\hline \multicolumn{8}{|l|}{ Agro by-product } \\
\hline Cottonseed cake & 89.33 & 25.15 & 65.28 & 43.54 & 8.35 & 71.04 & 9.73 \\
\hline Maize bran & 94.13 & 16.15 & 42.19 & 10.08 & 1.97 & 74.64 & 10.44 \\
\hline \multicolumn{8}{|l|}{ Herbage } \\
\hline Cenchrus biflorus & 85.28 & 17.78 & 49.79 & 34.31 & 7.13 & 65.76 & 8.96 \\
\hline \multicolumn{8}{|l|}{ Browse } \\
\hline Vitellaria paradoxa (leaf) & 90.43 & 11.15 & 41.09 & 32.79 & 12.64 & 58.56 & 8.69 \\
\hline Sclerocarya birrea (leaf) & 93.67 & 14.98 & 45.28 & 44.88 & 18.27 & 41.06 & 6.25 \\
\hline Guiera senegalensis (leaf) & 96.69 & 10.97 & 49.11 & 43.43 & 14.89 & 55.77 & 8.62 \\
\hline Ziziphus mauritiana (leaf) & 93.77 & 17.76 & 45.28 & 30.87 & 8.77 & 64.99 & 9.70 \\
\hline Saba senegalensis (leaf) & 90.07 & 10.12 & 36.36 & 28.47 & 12.69 & 51.46 & 7.86 \\
\hline
\end{tabular}

DM: dry matter; OM: organic matter; CP: crude protein; NDF: neutral detergent fiber; ADF: acid detergent fiber; ADL: acid detergent lignin; IVOMD: in vitro organic matter digestibility; ME: metabolizable energy $(\mathrm{MJ} / \mathrm{kg} \mathrm{DM})$ 
DISCUSSION

\section{Flock structure and dynamics}

Females, irrespective of the group, dominated sheep and goat flocks. At least $80 \%$ of the sheep flock were female at the beginning of the study, and at least $75 \%$ of the goat flock were female at the same period. These results are similar to those reported by Wilson (1986) in the agropastoral system of Central Mali (at least $75 \%$ of the sheep and goat flocks). Generally, females dominate the flock for reproduction and flock growth; the offtake rate of male sheep and goats is often high compared to that of females, as males are often sold to meet household cash needs (Ba et al., 1996). In our study, we did not collect sex disaggregated data for the offtake but anecdotal evidence from the participating households who supported the claim that offtake was higher in males than in females. Generally, the number of available animals, ready cash needs, prevailing market prices, age and condition of the animals influenced the offtake. Interventions that led to a significant increase in the flock size will tend to increase offtake as shown by the significant difference between the offtake rates in the two groups in our study. In Mali and other West Africa Sahelian countries, sale of small ruminants is one of the key strategies to cope with crop failure (Lebbie, 2004). The annual offtake rates for sheep and goat flocks in our study were similar to those of 29.5\% reported by Ejlertsen et al. (2012) in Southern Mali. Wilson (1986) reported lower offtake rates (19-26\%) for small ruminants in agropastoral systems in Central Mali.

The average sheep and goat flock size per household at the beginning of the study was lower than that of 9.48 and 23.57, respectively, reported by Wilson (1986) in agropastoral flocks in Central Mali. The larger flock size in agropastoral flocks than in mixed crop-livestock flocks in Southern Mali is to be expected as the farmers are more oriented toward cropping than rearing livestock, whereas agropastoralists are livestock keepers by tradition although they have settled down to grow crops (Ayantunde et al., 2011).

Feed and health interventions also led to a significant increase in the flock size of sheep and goats within a short period through better reproductive and growth performance. Ba et al. (1996) reported similar results in Mali when introducing health treatment alone. Konlan et al. (2017), and Avornyo et al. (2015) also reported synergistic benefits of the combined effect of providing concentrate feed and healthcare to small ruminants kept by smallholder farmers in Northern Ghana.

The results on flock dynamics confirmed that the mortality rate is always high in a small ruminant flock without adequate healthcare and nutrition (Konlan et al., 2017). According to Wilson (1986), the mortality rate can be up to $30 \%$ in sheep and goat flocks in Central Mali extensive livestock systems, where healthcare is inadequate and nutrition poor, particularly in the dry season. Ejlertsen et al. (2012) reported mortality rates of $25-32 \%$ in sheep flocks and $13-23 \%$ in goat flocks in Southern Mali based on a recall survey. The major causes of death in both sites were similar, namely respiratory problems, diarrheas and fever, losses due to predators, and injuries. Ba et al. (1996) reported similar causes of death in small ruminant flocks in a semi-arid area of Mali. There has not been any report on an animal disease only present in the control site, but a disease could have contributed to the high mortality rate we observed there.

\section{Body weight development and growth}

The ADG values for sheep and goats in the control and treatment groups were similar to those reported by Avornyo et al. (2015) for sheep and goats, and by Konlan et al. (2017) for sheep in studies on feed supplementation and provision of healthcare (17.8 and $45.4 \mathrm{~g} / \mathrm{day}$ for sheep under control and healthcare, respectively). The live weights of goats and sheep at 3 and 12 months in our study were lower than those reported by Wilson (1986) with $7 \mathrm{~kg}$ for goats and $9 \mathrm{~kg}$ for sheep at 3 months, and $18 \mathrm{~kg}$ for goats and $24 \mathrm{~kg}$ for sheep at 12 months of age. This could be attributed mostly to differences in feeding levels, as well as to the breed, as the Sahelian long-legged is the main sheep and goat breed in the agropastoral systems of Central Mali; it is heavier than the West Africa Dwarf, the dominant breed in Southern Mali. The higher body weight of sheep and goats starting at four months of age and significant at one year suggests that the effect of supplementary feeding and healthcare on body weight development is cumulative.

\section{Manure production and nutrient content}

The results showed that feed and health interventions were also beneficial for soil fertility improvement as the farmers could collect more manure to apply to their crop fields. The main challenge of manure collected at homesteads was transportation to the crop field, particularly if it was far from the village. The higher quantities of manure collected in the late dry season than in the wet season could be attributed to the longer time spent by the animals around the homestead in the late dry season since there was nearly no feed in grazing areas at this period. In the wet season, it was generally more difficult to collect manure as the water content in feces was high. The amounts of manure collected from animals in both groups (Table IV) were much lower than those of 10 to $13 \mathrm{~g} \mathrm{DM} / \mathrm{kg}$ live weight / day reported by Ayantunde et al. (2007) in sheep under feeding trials using fecal collection bags. This shows that there were losses in the collection of manure by farmers in our study. Actually, the manure deposited by the animals during grazing could not be collected and this could explain the lower quantities recorded.

The nitrogen and phosphorus concentrations in the manure in our study were much higher than those of 10.7 to $12.8 \mathrm{~g} / \mathrm{kg} \mathrm{DM}$ and 1.9 to $2.8 \mathrm{~g} / \mathrm{kg}$ DM, respectively, reported by Ayantunde et al. (2007) with sheep fed groundnut haulms as a supplement in the early dry season in Niger. The higher values in our study could be partly attributed to a better quality feed in Southern Mali than millet straw used as basal feed, and groundnut haulms used as a supplement in Ayantunde et al. (2007), since a high nutrient feed will generally result in a higher nutrient content in manure (Ayantunde et al., 2018). The manure had been permeated by urine, feedstuffs offered to the animals and dust, which might also have contributed to the higher values obtained in this study. Indeed the manure collected by the households to spread on crop fields was often a mixture of feces and urine, showing that some nutrients returned to the soil. Higher manure nitrogen and phosphorus contents were observed in the treatment group than in the control group, again confirming that better nutrition results in better manure quality.

\section{Nutritional quality of available feed resources}

The crude protein contents of cowpea hay and groundnut haulms in this study were higher than those reported by Umutoni and Ayantunde (2014). This could be attributed to the period of collection (immediately after the grain harvest in October) and the associated differences in the leaf to stem ratio. Legume residues such as cowpea hay and groundnut haulms are usually collected immediately after harvest in the early dry season, then stored and used to feed the animals in the dry season or sometimes sold as prices are often high (Ayantunde et al., 2014). Cereal straws are usually left on the field to be grazed by the animals. However, some farmers collect and store them to feed the household flocks. The quantity and quality of feed resources decreased as the dry season progressed. In addition, the availability of crop residues decreased as the dry season progressed while that of browse increased. Fodder trees and shrubs play an important role in ruminant nutrition in the late dry season (March to May) in the West African Sahel (Ickowicz and Mbaye, 2001). Browses are major feed resources in the late dry season when there is feed scarcity (Umutoni 
and Ayantunde, 2014) and they generally have a high crude protein content, but they are high in lignin content which limits intake and digestibility. The preference for browse species varied according to the season and the animal species. Goats tended to prefer browses compared to sheep; hence, browses are a significant part of the goat diet during the late dry season (Zampaligré et al., 2013).

\section{Partial cost and benefit analysis}

The results showed that traditional small ruminant production with low inputs (no supplementary feeds and minimal health interventions) is profitable provided there is no major disease outbreak, which could explain why smallholder farmers rear them. However, the farmers could generate more revenues by providing supplementary feed and healthcare to their small ruminants. For households with large size flocks, it is not only profitable but it is also advised to provide supplementary feed and standard healthcare (vaccination against PPR and pasteurellosis, deworming and curative measures) to their animals. With reported mortality rate of $80 \%$ (Ba et al., 1996) the risk is high to lose most of the animals in the event of a major disease outbreak such as PPR. The annual profits reported in this study were lower than those of 362,700 FCFA obtained from 100 dairy sheep, and 476,400 FCFA obtained with 100 dairy goats by Nantoumé et al. (2011) in Kaye region of Mali. If the annual profits reported by Nantoumé et al. (2011) were adjusted to the flock size in our study, the annual profits in our study would be higher than the returns from dairy sheep and goats. Our results confirmed that feed and health interventions to improve small ruminant production could be profitable. It is however critical to provide farmers with access to animal care services.

Crop residues, particularly leguminous crop residues such as cowpea hay or groundnut hay could be used as feed supplements instead of very expensive cottonseed cakes to reduce feed cost. In addition, in the area context, health intervention alone (vaccination against PPR, pasteurellosis and trypanosomosis at a cost of 175 CFA per animal) might be much more profitable than combined health and feed interventions. This could be elucidated through further research involving four groups (control, feed supplementation alone, health intervention alone, combined feed and health) instead of the two of this study.

\section{CONCLUSION}

Feed and health interventions led to profitable flock growth of sheep and goats within a short period by the significant increase in the birth rate and reduction of the mortality rate. This rapid flock growth increased offtake opportunities for the households. Supplementary feeding improved body weight development and increased the quantities of manure available to fertilize crop fields. Traditional small ruminant production with low external inputs is profitable as long as there is no major disease outbreak and there is a good feed resource base as in Southern Mali, but some additional income can be generated if the household invests in supplementary feeding and healthcare of the flock. This study showed that small ruminant husbandry could be profitable even with provision of supplementary feed and healthcare. However, the main challenge the smallholder farmers may face is the unavailability of veterinary services.

\section{Acknowledgments}

We are grateful to the farmers in Sirakele and Zanzoni in Koutiala District for their kind participation. Furthermore, we thank the Association malienne d'éveil pour le développement durable (AMEDD) for their support in data collection. This study was conducted under the Feed the Future Africa RISING project in West Africa funded by USAID. The authors are solely responsible for the opinions expressed in this paper.

\section{Author contributions statement}

AAA participated in the design and planning of the study, wrote the first draft and reviewed the manuscript; CU participated in the planning of the study and reviewed the manuscript; TD, KS and OS participated in the planning of the study and collected the data; all authors authorize the submission of the final version for publication.

\section{REFERENCES}

Avornyo F.K., Ayantunde A., Shaibu M.T., Konlan S.P., Karbo N., 2015 Effect of feed and health packages on the performance of village small ruminants in Northern Ghana. Int. J. Livest. Res., 5: 91-95, DOI 10.5455/ ijlr.20150717102356

Ayantunde A.A., Blummel M., Grings E., Duncan A.J., 2014. Price and quality of livestock feeds in suburban markets of West Africa's Sahel: Case study from Bamako, Mali. Rev. Elev. Med. Vet. Pays Trop., 67 (1): 13-21, doi: 10.19182/ remvt. 10155

Ayantunde A.A., de Leeuw J., Turner M.D., Said M., 2011. Challenges of assessing the sustainability of (agro) pastoral systems. Livest. Sci., 139: 30-43, doi: 10.1016/j.livsci.2011.03.019

Ayantunde A.A., Delfosse P., Fernández-Rivera S., Gerard B., Dan Gomma A., 2007. Supplementation with groundnut haulms for sheep fattening in the West African Sahel. Trop. Anim. Health Prod., 39: 207-216, doi: 10.1007/ s11250-007-9009-1

Ayantunde A., Hiernaux P., Fernandez-Rivera S., Sangare M., 2018. Nutrient management in livestock systems in West Africa Sahel with emphasis on feed and grazing management. In: Improving the profitability, sustainability and efficiency of nutrients through site specific fertilizer recommendations in West Africa agro-ecosystems (Eds. Bationo A., Ngaradoum D., Youl S., Lompo F., Fening J.). Springer, Cham, UK, 11-23, doi: 10.1007/978-3-319-58789-9_2

Ba S.B., Udo H.M.J., Zwart D., 1996. Impact of veterinary treatments on goat mortality and offtake in the semi-arid area of Mali. Small Rum. Res., 19: 1-8, doi: 10.1016/0921-4488(95)00740-7

Ben Salem H., Smith T., 2008. Feeding strategies to increase small ruminant production in dry environments. Small Rum. Res., 77: 174-194, doi: 10.1016/j. smallrumres.2008.03.008

De Boever J.L., Cottyn B.G., Vanacker J.M., Boucque C.V., 1995. The use of NIRS to predict the chemical composition and the energy value of compound feeds for cattle. Anim. Feed Sci. Tech., 51: 243-253, doi: 10.1016/0377-8401(94)00695-6

Ejlertsen M., Poole J., Marshall K., 2012. Sustainable management of globally significant endemic ruminant livestock in West Africa: Estimates of livestock demographic parameters in Mali; Res. Rep. 31. ILRI, Nairobi, Kenya

Ickowicz A., Mbaye M., 2001. Forêts soudaniennes et alimentation des bovins au Sénégal: potentiel et limites. Bois For. Trop., 55: 47-61

Konlan S.P., Ayantunde A., Addah W., Dei H.K., 2017. The combined effects of the provision of feed and healthcare on nutrient utilization and growth performance of sheep during the early or late dry season. Trop. Anim. Health Prod., 49: 1423-1430, doi: 10.1007/s11250-017-1343-3

Lebbie S.H.B., 2004. Goats under household conditions. Small Rum. Res., 51 131-136, doi: 10.1016/j.smallrumres.2003.08.015

Nantoumé H., Kouriba A., Diarra C.H.T., Coulibaly D., 2011. Amélioration de la productivité des petits ruminants : moyen de diversification des revenus et de lutte contre I'insécurité alimentaire. Livest. Res. Rural Dev., 23 (5), 110

SAS Institute, 1987. SAS/STAT for personal computers. Cary, NC, USA, SAS Institute

Umutoni C., Ayantunde A.A. 2014. Evaluation of feed resources in mixed croplivestock systems in the Sudano-Sahelian zone of Mali. Africa RISING Project. Tech. Rep. May 2014. ILRI, Nairobi, Kenya

Wilson R.T., 1986. Livestock production in central Mali: Long-term studies on cattle and small ruminants in the agro-pastoral systems. Res. Rep. 14. ILCA, Addis Ababa, Ethiopia, 113 p.

Wilson R.T., 1991. Small ruminant production and small ruminant genetic resource in tropical Africa. FAO, Rome, Italy, 231 p. (Animal Prod. Health Paper; 88)

Zampaligre N., Dossa H.L., Schlecht E., 2013. Contribution of browse to ruminant nutrition across three agro-ecological zones of Burkina Faso. J. Arid Environ., 95: 55-64, doi: 10.1016/j.jaridenv.2013.03.011 


\section{Résumé}

Ayantunde A.A., Umutoni C., Dembele T., Seydou K., Samake O. Effets des interventions alimentaire et sanitaire sur la production des petits ruminants dans les systèmes de production mixtes agriculture-élevage au sud du Mali

Les petits ruminants font partie intégrante des systèmes de production mixtes agriculture-élevage au Mali et jouent divers rôles dans la sécurité alimentaire des ménages en tant que sources de viande et de lait, et de moyens de revenus supplémentaires pour répondre aux besoins alimentaires et pécuniaires. Cependant, la production des petits ruminants est compromise par la mauvaise performance des animaux, principalement due à une alimentation inadéquate et aux maladies. Une étude pilote associant des interventions alimentaire et sanitaire a été menée dans deux villages, Sirakele et Zanzoni, dans le district de Koutiala dans le sud du pays. L'objectif était d'évaluer les effets de ces interventions combinées sur la production de petits ruminants dans des systèmes mixtes de culture et d'élevage. Zanzoni a servi de témoin tandis que Sirakele a bénéficié $d^{\prime}$ interventions alimentaire et sanitaire. Vingt ménages ont été sélectionnés au hasard dans chaque village et l'étude a duré un an, d'août 2016 à août 2017. Les résultats ont montré que, sur une année, la taille moyenne des troupeaux de chèvres et d'ovins a doublé dans le groupe avec interventions alimentaire et sanitaire, alors qu'elle est restée quasi la même dans le groupe témoin. Le taux de mortalité a été significativement plus faible dans le groupe avec traitement que dans le groupe témoin. De plus, les gains de poids des chèvres et des ovins ont été respectivement de 42,98 $\pm 3,28$ et $47,12 \pm 2,73 \mathrm{~g} /$ jour dans le groupe avec traitement, alors qu'ils n'ont été que de 22,59 $\pm 2,29$ et 16,58 $\pm 2,74 \mathrm{~g} /$ jour dans le groupe témoin. Les résultats ont confirmé que les interventions alimentaire et sanitaire amélioraient significativement la production des petits ruminants.

Mots-clés : petits ruminants, effectif du cheptel, polyculture élevage, sécurité alimentaire des ménages, Sahel

\section{Resumen}

Ayantunde A.A., Umutoni C., Dembele T., Seydou K., Samake O. Efectos de intervenciones en la alimentación y la salud sobre la producción de pequeños rumiantes en sistemas mixtos agrícolaganaderos en el sur de Malí

En Malí, los pequeños rumiantes son una parte integral de los sistemas mixtos de agricultura y ganadería, cumpliendo diversos roles en la seguridad alimentaria de los hogares, como fuentes de carne y leche, así como fuentes de ingresos adicionales para satisfacer las necesidades alimenticias y financieras. Sin embargo, la producción de pequeños rumiantes se ve afectada por el bajo rendimiento de los animales, debido principalmente a una nutrición inadecuada y a enfermedades. Se realizó un estudio piloto que combinó intervenciones sobre la alimentación y la salud en dos aldeas, Sirakele y Zanzoni en el distrito de Koutiala, en el sur del país. El objetivo fue evaluar los efectos de las intervenciones combinadas en la producción de pequeños rumiantes en sistemas mixtos de cultivos y ganado. Zanzoni sirvió como control, y Sirakele recibió intervenciones sobre la alimentación y la salud. Veinte hogares fueron seleccionados al azar en cada aldea y el estudio duró un año, de agosto de 2016 a agosto de 2017. Los resultados mostraron que, en un año, el tamaño promedio de los rebaños de cabras y ovejas en el grupo de intervención sobre los alimentos y la salud se duplicó, mientras que en el grupo control se mantuvo más o menos igual. La tasa de mortalidad fue significativamente menor en el grupo de tratamiento que en el control. Además, las cabras y las ovejas ganaron 42,98 $\pm 3,28$ y 47,12 $\pm 2,73 \mathrm{~g}$ /día en el grupo de tratamiento, respectivamente, mientras que solo ganaron $22,59 \pm 2,29$ y $16,58 \pm 2,74 \mathrm{~g} /$ día en el grupo de control, respectivamente. Los resultados confirmaron que las intervenciones sobre la alimentación y la salud mejoraron significativamente la producción de pequeños rumiantes.

Palabras clave: pequeños rumiantes, número de cabezas, explotación agrícola combinada, seguridad alimentaria en el hogar, Sahel 